\title{
Real-time PCR in Clinical Diagnostic Settings
}

\section{Sumathi Sankaran-Walters}

Department of Medical Microbiology and Immunology, University of California Davis, Davis, California, USA

\section{Introduction}

Real-time PCR is a commonly used technique for the detection of pathogens both in research setting, as well as in diagnostic settings [1]. The goal of this editorial is to introduce or familiarize the reader with the advantages of using the available methodologies in a targeted manner. Real-time PCR combines PCR chemistry with either a fluorescent probe or DNA detection dyes such as syber green, thus allowing visualization of product in "real-time" [2]. The available real-time PCR methodologies provide good sensitivity and specificity. The ease and speed of the design and setup process of qPCR makes it an attractive assay to use. PCR amplification is performed in a closed setting (one tube vs two tube) thus reducing the chances of contamination.

Choice of assay is very important as is the choice of clinical sampling. Clinical samples may consist of body fluids or tissue. The pathogen that is being investigated may be a bacteria, virus or parasite. The virus may be an RNA or DNA virus. To begin with, nucleotide isolation for the clinical specimen will include RNA, DNA or both. There are many available methods for nucleotide isolation. Studies have demonstrated varying levels efficiency of nucleotide isolation with various techniques [3-5]. Our studies and other have demonstrated in a stool sample, isolation of DNA of Bacteriodetes Species is more efficient using a silica-gel column-based method as compared to using phenol chloroform [5]. However the breadth of species representation is improved using phenol-chloroform extraction method. RNA isolation from plasma is more efficient using the silica-gel column method while identification of low-copy numbers viral RNA from human blood is more efficient following ultra-centrifugation.

Sample type and availability is also a factor in the choice of assay (Figure 1). Viral RNA/DNA and bacterial DNA are likely to be present in specific tissues as well as in blood. Identification of microbes starts with the isolation of the appropriate nucleic acid from the sample. For example, in the case of HIV, viral RNA and proviral DNA can be isolated from blood as well as from tissue sources [6]. Analysis of viral RNA will provide information regarding active viral replication and the plasma viral load which is a direct measure of clinical state during the course of HIV infection as well as a measure of effective therapy during HAART. Identification of the level of proviral DNA is a measure of the
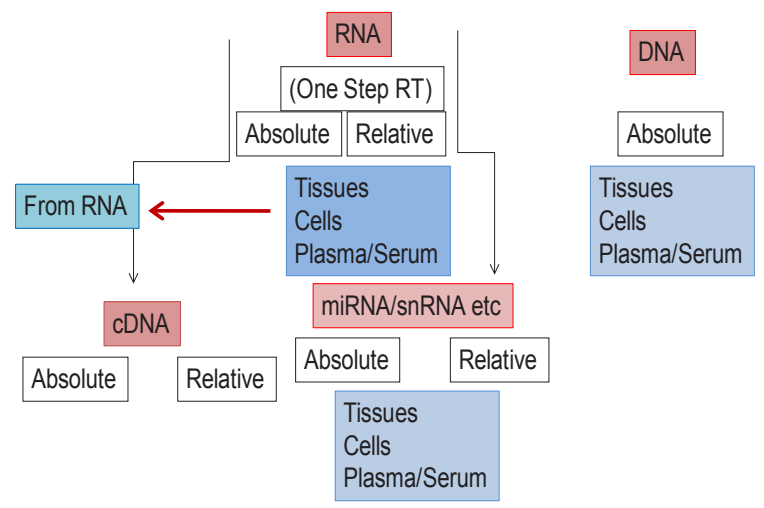

Figure1: Schematic of Possibilities. viral reservoirs during the course of HIV infection and is an important indicator during therapy. In this case, depending on which parameter is being investigated, the nucleic acid isolation methods and the choice of tissue sample vary. Identification of causative agents in disease states is also simplified by the use of real-time PCR assays. These assays provide a fast and specific method to identify bacterial pathogens in sepsis [7-9] and pneumonia [10-14], viral agents in hepatitis [15-18] and respiratory diseases [19].

A majority of the workflow utilized in this technology is automated with many hundreds of core facilities available around the world. The main factor that distinguishes between a successful assay and an unsuccessful one is the level of understanding of the outcomes available from the assay. Thus, the pre analytical steps that are followed prior to utilization of this methodology are critical to the success of the assay. This includes planning of the collection and storage of samples as well as a detailed plan of processing and analysis. The planning stage should include optimization, analysis of positive and negative controls and a practice run. Once all steps are in place, the real-time PCR platform provides a fast and convenient way to detect microbes of all origins in clinical samples.

\section{Acknowledgements}

I would like to thank the Lucy Whittier Molecular Core Facility and Dr. Emir Hodzic for their valuable input. Dr Sankaran is supported by a Building Interdisciplinary Research Careers in Women's Health award (K12 HD051958) funded by the $\mathrm{NICHD}, \mathrm{ORWH}$, and the NIA

\section{References}

1. Espy M.J, Uhl JR, Sloan LM, Buckwalter SP, Jones MF, et al. (2006) Real-time PCR in clinical microbiology: applications for routine laboratory testing. Clin Microbiol Rev 19: 165-256.

2. Mayer G, Muller J, Lunse CE (2011) RNA diagnostics: real-time RT-PCR strategies and promising novel target RNAs. Wiley Interdiscip Rev RNA 2: 32-41.

3. Mygind T, Østergaard L, Birkelund S, Lindholt JS, Christiansen G (2003) Evaluation of five DNA extraction methods for purification of DNA from atherosclerotic tissue and estimation of prevalence of Chlamydia pneumoniae in tissue from a Danish population undergoing vascular repair. BMC Microbiol 3: 19.

4. Baddour MM, Alkhalifa DH (2008) Evaluation of three polymerase chain reaction techniques for detection of Brucella DNA in peripheral human blood. Can J Microbiol 54: 352-357.

5. McOrist AL, Jackson M, Bird AR (2002) A comparison of five methods for extraction of bacterial DNA from human faecal samples. J Microbiol Methods 50: $131-139$.

6. Agarwal A, Sankaran S, Vajpayee M, Sreenivas V, Seth P, et al. (2007) Correla-

*Corresponding author: Sumathi Sankaran-Walters, Department of Medical Microbiology and Immunology, University of California Davis, Davis, California, USA, E-mail: ssankara@ucdavis.edu

Received May 08, 2012; Accepted May 09, 2012; Published May 14, 2012

Citation: Walters SS (2012) Real-time PCR in Clinical Diagnostic Settings. J Med Microb Diagn 1:e106. doi:10.4172/2161-0703.1000e106

Copyright: (c) 2012 Walters SS. This is an open-access article distributed under the terms of the Creative Commons Attribution License, which permits unrestricted use, distribution, and reproduction in any medium, provided the original author and source are credited. 
tion of immune activation with HIV-1 RNA levels assayed by real-time RT-PCR in HIV-1 subtype C infected patients in Northern India. J Clin Virol 40: 301-306.

7. Grif K, Fille M, Würzner R, Weiss G, Lorenz I, et al. (2012) Rapid detection of bloodstream pathogens by real-time PCR in patients with sepsis. Wien Klin Wochenschr.

8. Dark P, Wilson C, Blackwood B, McAuley DF, Perkins GD, et al. (2012) Accuracy of LightCycler(R) SeptiFast for the detection and identification of pathogens in the blood of patients with suspected sepsis: a systematic review protocol. BMJ Open 2: e000392.

9. Ohlin A, Bäckman A, Ewald U, Schollin J, Björkqvist M (2011) Diagnosis of Neonatal Sepsis by Broad-Range 16S Real-Time Polymerase Chain Reaction. Neonatology 101: 241-246.

10. Wang L, Gu H, Lu X (2012) A rapid low-cost real-time PCR for the detection of Klebsiella pneumonia carbapenemase genes. Ann Clin Microbiol Antimicrob 11: 9 .

11. Nomanpour B, Ghodousi A, Babaei A, Abtahi H, Tabrizi M, et al. (2011) Rapid, cost-effective, sensitive and quantitative detection of Acinetobacter baumanni from pneumonia patients. Iran J Microbiol 3: 162-169.

12. Orsi CF, Gennari W, Venturelli C, La Regina A, Pecorari M, et al. (2012) Performance of 2 commercial real-time polymerase chain reaction assays for the detection of Aspergillus and Pneumocystis DNA in bronchoalveolar lavage fluid samples from critical care patients. Diagn Microbiol Infect Dis.
13. Henke-Gendo C, Ganzenmueller T, Kluba J, Harste G, Raggub L, et al. (2012) Improved quantitative PCR protocols for adenovirus and CMV with an internal inhibition control system and automated nucleic acid isolation. J Med Virol 84 890-896.

14. Qin T, Xia J, Ren H, Zhou H, Tang B, et al. (2012) Liver cirrhosis as a predisposing condition for Legionnaires' disease: a report of four laboratory-confirmed cases from China. J Med Microbiol.

15. Pongsiri $\mathrm{P}$, Praianantathavorn $\mathrm{K}$, Theamboonlers A, Payungporn S, Poovorawan Y (2012) Multiplex real-time RT-PCR for detecting chikungunya virus and dengue virus. Asian Pac J Trop Med 5: 342-346.

16. Shi J, Basangzhuoma, Xing Z, Yangla, Cui C (2012) Establishment of rapid and specific real-time PCR assays for the detection of hepatitis $B$ viral genotype in tibet. J Virol Methods.

17. Chancey C, Winkelman V, Foley JB, Silberstein E, Teixeira-Carvalho A, et al (2012) Distribution of hepatitis C virus in circulating blood components from blood donors. Vox Sang.

18. Putz-Bankuti C, Kessler HH, Schilcher G, Schneditz D, Konrad PM, et al. (2012) Increase of HCV RNA concentration during hemodialysis treatment in patients with chronic hepatitis C. J Clin Virol 54: 110-114.

19. Gu Z, Belzer SW, Gibson CS, Bankowski MJ, Hayden RT (2003) Multiplexed real-time PCR for quantitative detection of human adenovirus. J Clin Microbiol 41: 4636-4641. 